\title{
Poor, Pitiful Monsters From Homer to Borges
}

\author{
Robin McAllister \\ Sacred Heart University, Fairfield, Connecticut, USA
}

\begin{abstract}
This article reviews famous monsters in Western literature that reveal a hidden humanity or affinity with the hero that elicits compassion or emphasizes their bestiality in surprising ways. Their monstrosity is often a distorted mirror image of the hero's humanity. Shakespeare's Caliban is a famous example of the affinity between monster and protagonist. Homer's Polyphemus, the first monster in Western tradition establishes certain traits that persist through later literature: lawless, barbarian, cannibal, and giant. Polyphemus hates men, but loves his old ram. Grendel, Grendel's mother, and the dragon in Beowulf are giants, lawless, cannibals. The dragon Beowulf dies fighting anticipates the identity between hero and monster that Borges makes explicit in Asterion, the Minotaur. Dante's Satan in the Inferno fails to leave later successors. In Borges's “The House of Asterion” the Minotaur is both monster and hero. Asterion's affinities with other protagonists in Borges' stories suggest that the monster in the labyrinth is not the Minotaur, but the concept of infinity.
\end{abstract}

Keywords: monsters, Homer, Beowulf, Borges

\section{Introduction}

“...This thing of darkness I/ acknowledge mine” (Kittredge, 1939, p. 39; V. i. 275-276) Prospero, the magician playwright protagonist of Shakespeare's The Tempest, accepts his affinity with the monster, Caliban (perhaps a pun on "cannibal") and continues a long tradition in Western literature of monsters who reveal a hidden humanity or affinity with the hero that elicits compassion or emphasizes their bestiality (suggested by their cannibalism) in surprising ways. Their very monstrosity is a distorted mirror image of the hero's humanity: “You taught me language, and my profit on't/ Is, I know how to curse” (Kittredge, 1939, p. 19; I, ii, 363-364) Caliban retorts to Prospero. This article will review several of such monsters beginning with Homer's portrait of Polyphemous, the Cyclops, continuing with Grendel's mother and the dragon in Beowulf, and culminating with Jorge Luis Borges’s Minotaur in “La Casa de Asterion”.

\section{Homer's Polyphemus}

A monster depends on the eye of the beholder. Homer's Polyphemus, the first monster in Western literature, establishes certain traits that persist throughout literature. Odysseus describes him as lawless, lacking the technologies that set civilized men apart, agriculture and the building of ships, a cannibal. His size, like a shaggy mountain, is monstrous in itself. Odysseus's attitude toward him resembles an imperialist's from a conquering people describing indigenous people, who neither recognize the rich resources of their land nor have the technology to exploit them, an attitude found in Shakespeare's portrayal of Caliban in The Tempest. The Cyclops lives up to Odysseus words, refusing to acknowledge Zeus and the gods, and observing the law of

Robin McAllister, Associate Professor, Department of English, Sacred Heart University. 
hospitality, sacred to Zeus, by smashing the heads of Odysseus' men on the ground, killing them like puppies, and offering as his "guest gift” to Odysseus' skin of wine to eat Odysseus last of his men.

And yet Homer shows another side to Polyphemus's character which is more appealing. He may not like men, but he loves his old ram, the leader of the herd. As the blinded one-eyed monster runs his hands over the back of his sheep, searching for the escaping Greek warriors, Polyphemus seems to express a humane side hidden from his human victims:

Dear old ram, why last of the flock to quit the cave? In the good old days you'd never lag behind the rest-you with your long marching strides, first by far of the flock to graze the fresh young grasses ... but now you're last of all. And why? Sick at heart for your master's eye that coward gouged out with his wicked crew? ... Oh if only you thought like me, had words like me to tell me where that scoundrel is cringing from my rage! (Homer, 1996, p. 225)

The words of affection and empathy the Cyclops utters to the ram are rendered almost comical by the irony of his situation. Odysseus at that very moment is outwitting the Cyclops by clinging to the belly of the ram to escape from the cave. Polyphemus's words may also be Homer's way of emphasizing Polyphemus' bestial, subhuman nature.

\section{Grendel, Grendel's Mother and the Dragon in Beowulf}

Although the poet of Beowulf was unfamiliar with Homer, his description of the three monsters Beowulf encounters, Grendel, Grendel's mother, and the dragon that guards a burial chamber, shares the monstrosity of size and the disdain for the laws of men portrayed in the Cyclops. The Beowulf poet in his Christianization of the poem transforms the defeated pagan divinities into demons and traces their lineage to the outcast Cain, the first murderer and exile in Biblical history. Grendel and Grendel's mother too are cannibals. Yet their shapes are ambiguous, sometimes more human than animal. The aged warrior Hrothgar tells Beowulf:

I have heard landsmen, my people, hall-counselors, say this, that they have seen two such walkers in the wasteland holding to the moors, alien spirits. One of them, so far as they could clearly discern, was the likeness of a woman. The other wretched shape trod the tracks of exile in the form of a man, except that he was bigger than any other man. (Beowulf, 2000, p. 95)

Grendel is motivated to begin his attacks on the Geats by a certain longing and jealousy in his exclusion from God's created universe:

Then the fierce spirit painfully endured hardship for a time, he who dwelt in the darkness, for every day he heard loud mirth in the hall; there was the song of the scop. There he sang who could relate the beginning of men far back in time, said that the Almighty made earth, a bright field fair in the water that surrounds it, set up in triumph the lights of the sun and the moon to lighten land-dwellers, and adorned the surfaces of the earth with branches and leaves, created also life for each of the kinds that move and breathe. (Beowulf, 2000, p. 9)

Grendel's mother seeks revenge for the mortal wound Beowulf has inflicted on her son, tearing his arm off at the shoulder and exhibiting it in the rafters of the mead hall, Heorot. She carries back Grendel's arm to the eerie bottomless pond where she dwells. The dragon Beowulf dies fighting when he is an old king anticipates the identity between hero and monster we later encounter in Borges' Asterion, the Minotaur of Crete. The dragon is the guardian of gold buried in an ancient burial mound, which has been broken into by a thief who has stolen a goblet from the grave. The Beowulf poet has inserted an elegy into the narrative at this point, the Lay of the Last Survivor, the last words spoken by the man who had hidden the treasure before lying down to 
die in the barrow. The dragon Beowulf dies slaying is not just a scaly flying serpent, but clearly associated with the vengeful soul of the warrior buried there, whose tomb has been looted. Beowulf himself will soon join the Last Survivor and perhaps be metamorphosed into a guardian dragon.

\section{Dante's Satan}

Not all monsters persist through the history of literature like Polyphemus and Grendel. The central monster of Dante's Inferno, Satan, has never been able to compete with the popular image of the devil with horns, hooves, and a forked tail. Dante's Satan is a parody of the Trinity, frozen into a lake of ice of his own making, large as a windmill, with three faces, black, yellow, and red, weeping and chewing the bodies of the traitors of Christ and the Roman Empire. He is an ideological creation whose symbolic role detracts from his monstrous presence. Virgil and Dante mock Satan by climbing over his hairy buttocks to escape from the circles of Hell.

\section{Borges's Asterion}

Jorge Luis Borges writes as if he conceived many of his stories as carrying on a dialogue with departed predecessors in the Western literary tradition, like Homer (“The Immortal”), Dante ("The Aleph”), and Cervantes ("Pierre Menard, Author of the Quixote"), as if they were his contemporaries sharing a continuous tradition. In "The House of Asterion" the Minotaur is both the monster and the hero, like many other protagonists in Borges' fiction. Asterion, the Minotaur, shares their role as dreamers of metaphysical speculation lost or trapped in a labyrinth of human fate, a literal labyrinth in the Minotaur's case. "A labyrinth is a structure compounded to confuse men; its architecture, rich in symmetries, is subordinated to that end" (Borges, 1962, p. 110), the protagonist of Borges' “The Immortal” writes. As for the magus in "The Circular Ruins,” Asterion’s labyrinth is a "minimum of visible world” (Borges, 1962, p. 46). Only in retrospect, after reading the story, does the reader realize that Asterion's house is the labyrinth, a labyrinth both inside the infinite universe and the infinite universe itself:

All the parts of the house are repeated many times, any place is another place. There is no one pool, courtyard, drinking trough, manger; the mangers, drinking troughs, courtyards, pools are fourteen (infinite) in number. The house is the same size as the world; or rather, it is the world... Everything is repeated many times, fourteen times, but two things seem to be only once: above, the intricate sun; below, Asterion. Perhaps I have created the stars and the sun and this enormous house, but I no longer remember. (Borges, 1962, p. 139)

Only in retrospect after reading the story, does the reader realize Asterion is the Minotaur. Contrary to received tradition, he is not a prisoner of the labyrinth. "It is true,” Asterion tells us,

...that I never leave my house, but it is also true that its doors (whose number is infinite) are open day and night to men and to animals as well. Anyone may enter... Besides, one afternoon I did step into street; if I returned before night, I did so because of the fear that the faces of the common people inspired in me, faces as discolored and flat as the palm of one’s hand. (Borges, 1962, p. 138)

Asterion combines in himself both human nature and bestial, and he aspires to embrace the divine nature he has inherited through his mother Pasiphae, who is the daughter of Helios, the sun. When he mentions his fear and revulsion of human faces, he speaks in his role as a bull. He aspires to divinity in his rejection of letters and writing:

...Like the philosopher, I think that nothing is communicable by the art of writing. Bothersome and trivial details have no place in my spirit, which is prepared for all that is vast and grand; I have never retained the difference between one 
letter and another. A certain generous impatience has not permitted that I learn to read. Sometimes I deplore this, for the nights and days are long. (Borges, 1962, p. 139)

Asterion is a Minotaur with complex human feelings, arrogance, misanthropy, fear, loneliness. To distract himself he runs through the corridors until he falls dizzily to the floor. His favorite game is to pretend that there is another Asterion who comes to visit him, and Asterion shows him courteously through the intersections and courtyards. "Sometimes I make a mistake and the two of us laugh heartily" (Borges, 1962, p. 139), Asterion adds. He shows no remorse over the deaths of the nine sacrificial men from Athens, but rather speaks as if he is their redeemer or savior: "I hear their steps or their voices in the depths of the stone galleries and I run joyfully to find them. The ceremony lasts a few minutes. They fall one after another without my having to bloody my hands” (Borges, 1962, p. 140). One of them has prophesied at the moment of his death that someday Asterion's redeemer will come:

Since then my loneliness does not pain me, because I know my redeemer lives and he will finally rise above the dust. If my ear could capture all the sounds of the world, I should hear his steps. I hope he will take me to a place with fewer galleries and fewer doors. (Borges, 1962, p. 140)

Like many of Borges' stories, “The House of Asterion” is structured as a quest journey, but a quest that has been reduced to the final, crucial encounter of the protagonist and the monster, who share a single destiny, and reveal their shared identity only at the moment of the minotaur's death, when the names of Theseus and the minotaur are revealed for the first and last times: “'Would you believe it, Ariadne?' said Theseus. 'The Minotaur scarcely defended himself’” (Borges, 1962, p. 140).

\section{Conclusion}

Why does Asterion long for a redeemer? From what does he need redemption? The magus in "The Circular Ruins" who dreams another man into existence only to discover that he too is being dreamed by someone else dreams of a circular amphitheater filled with potential candidates for the magician to dream into reality, or, as the dreamer, magus puts it, "to redeem one of them from his state of vain appearance and interpolate him into the world of reality” (Borges, 1962, p. 46). Asterion's affinities with other dreamers, detectives, and searchers in Borges' "The Circular Ruins”, “The Immortal”, and, particularly, "Death and the Compass” with its killing symmetries suggest that the monster in the labyrinth is not the Minotaur, but Borges' preoccupation with the concept of infinity and the use of infinite regress in his fictions to deplete his protagonists of identity and reality. The man dreamed by a man who is dreamed in turn by another is a perfect example of Borges' use of infinite regress as a structural and thematic principle. Infinity, Borges tells us in "Avatars of the Tortoise” is the "concept which corrupts and upsets all others” (Borges, 1962, p. 202). Absolute space, movement, chronological time, reality and appearance, all dissolve and disappear in the multiple mirrors of infinity, a monster that cannot be defeated.

\section{References}

Beowulf. (2000). S. Heaney, (Trans.). New York: W.W. Norton.

Borges, J. L. (1962). Labyrinths: Selected stories and other writings. D. A. Yates, and J. E. Irby, (Eds.). New York: A New Directions Book.

Homer. (1996). The Odyssey. (R. Fagles, Trans.). New York: Penguin Books.

Kittredge, G. L. (Ed.). (1939). Sixteen plays of Shakespeare. Boston: Ginn and Company. 